\title{
PARTICIPATION IN URBAN PLANNING AND THE POST-SOCIALIST LEGACY. REVISITING MAIER'S HYPOTHESIS THROUGH THE CASE OF HUNGARY
}

Zoltán BAJMÓCYa

\author{
${ }^{a}$ University of Szeged, Faculty of Economics and Business Administration Research Centre, H-6722 \\ Szeged, Kálvária sgt. 1., bajmocyz@eco.u-szeged.hu
}

Cite this article: Bajmócy, Z. (2021). Participation in Urban Planning and the Post-Socialist Legacy. Revisiting Maier's Hypothesis Through the Case of Hungary. Deturope, 13(1), 4-23.

\begin{abstract}
According to Maier's (2001) hypothesis, the democratization process in post-socialist countries would lead to the increased importance of stakeholder and citizen participation in urban planning. Increasing circles of stakeholders would be able to join and become empowered. The objective of the present paper is to revisit Maier's hypothesis in the Hungarian context. We attempt to shed light on the main factors that shape the framework conditions of participation in urban planning; we ask if the three decades of transition can be described as an approximation to the Western standards in urban planning, as Maier suggested.

We conducted 49 semi-structured interviews in three Hungarian middle-sized cities with various stakeholders of urban planning. We carried out qualitative content analysis based on inductive coding in order to identify the underlying factors, which shape the framework conditions of participation. We managed to identify six factors. They have mostly accumulated since the fall of the socialist era, the postsocialist legacy may only have indirect effects on them. These six factors add up to a halt in the democratization of planning and the serious limits to consensus building. We argue that these two processes diverted Hungary from the path Maier envisioned, and make the Hungarian context for participation and participatory techniques fundamentally different from the Western-European contexts.
\end{abstract}

Keywords: participation, urban planning, post-socialist, Maier's hypothesis, Hungary

\section{INTRODUCTION}

Stakeholders' and citizens' participation has been at the forefront of urban planning inquiry for decades now. Arguments in favour of participation have been put forth alongside various concepts, such as urban justice or public interest.

One of the strongest contemporary approaches of urban planning (communicative planning theory) explicitly addresses the issue of collaborative planning (Innes, 1995; Healey, 1997, 2010). The basic assumption here is that "the stronger the role of disadvantaged groups in policy decisions, the more redistributional will be the outcomes" (Fainstein, 2014, p. 9). Apart from arguments on urban justice, communicative planning theory also provides a comprehensive criticism on the "rational model" of planning. Collaboration makes planning better also in terms of reflecting public interest. As Innes and Booher (2015, p. 207) argue: 
"Process versus outcome is [...] a false dichotomy. Stakeholders engage in a process because they care about the outcome. Aspects of process are part of the outcome through communication power. People who are brought to the table and heard and who learn, influence, and build relationships are changed and the power relationships themselves are changed."

Another strong body of the literature argues for the "right to the city" (Harvey, 1973, 2003; Marcuse, 2009; Basta, 2017). As Harvey (2003, p. 949) formulates the concept: "the right to the city is not merely a right of access to what already exists, but a right to change it after our heart's desire."

A set of recent arguments emphasise that the aggregation of personal interests and welfare judgements into public interest requires open public debates and collective decisions; it is not an exercise that could be carried out by an "objective external observer" (Biggeri \& Ferrannini, 2014; Bajmócy \& Gébert, 2014; Fainstein, 2014; Basta, 2016). This emerging body of literature is inspired by the capability approach proposed by the Nobel-laureate Amartya Sen $(1999,2009)$ This approach also highlights that beside the instrumental value of participation (it may lead to better results) it also has an intrinsic value for well-being (the freedom to participate is a valued option, and as such, an element of well-being).

Accordingly, the theory and practice of stakeholders' and citizens' participation have been integral parts of urban planning for decades now. However, in the post-socialist member states of the European Union (EU) it only started to gain attention around the fall of the socialist regimes. In these post-socialist countries, the increasing importance of participation was strongly connected to the EU accession process and the planning requirements imposed by the EU development funds.

While the legacy of the post-socialist members was the (almost total) lack of participation, this started to change gradually. Karel Maier (2001) in his well-received paper put forth a hypothesis, that in post-socialist countries gradually more and more interest groups will be represented in the planning process; and these interest groups will gradually become empowered to get closer to the power centre. Maier (2001) implicitly argued that the postsocialist member states would gradually move towards urban planning processes, which are similar to the Western-European standards.

The present paper attempts to re-examine this hypothesis through the case of Hungary. Three decades after the regime change, the post-socialist countries show huge differences. However, in many of them, stakeholder and citizen participation (either strategic or land-use planning) still significantly differs from Western standards (e.g., Tsenkova, 2007; Czupich, 2018; Bajmócy, Gébert, Málovics, Méreiné \& Juhász, 2020). While having knowledge on 
how participation in urban planning looks like in post-socialist countries, we mostly lack analyses on why participation occurs in certain ways (alongside certain process designs) and to what extent it is a post-socialist legacy.

Therefore, the objective of the present paper is to revisit Maier's hypothesis in the Hungarian context. On this basis, we formulated two research questions: (1) what are the main factors that shape the framework conditions of participation in urban planning; and (2) can we describe the three decades of transition as an approximation to the Western standards in urban planning, as Maier suggested?

Section 2 introduces Maier's hypothesis and its context. Section 3 outlines the most important changes in the Hungarian context with regard to participation in urban planning since the regime change. In Section 4 we introduce the methodology of our interview-based empirical analysis. Section 5 demonstrates our results. We provide discussion and conclusions in Section 6.

\section{The context of Maier's hypothesis}

Instances of bottom-up participation in the socialist countries already emerged in the 1980s (e.g. Bőhm, 1987). These were mainly connected to certain “emergencies” (e.g. government's intention to merge certain settlements; the intention of certain settlements to become independent; or environmental issues) and occurred in the form of civic opposition. However, participation in the Western European sense could not occur yet.

For many people, the changing of the political order in the countries of Central and Eastern Europe (CEE) promised the reintegration into the Western European trend of social change. According to wide-spread expectations, the transition countries would adapt the social patterns of countries with longer democratic traditions, which provide space for active citizenship, participation, transparency and community control (Jávor \& Beke, 2013).

This promise was strongly reflected by discussions about urban planning as well. The possibility for unique CEE development paths was not denied. According to Healey and Williams (1993, p. 704): "It remains to be seen what kinds of approaches to spatial planning will evolve in these contexts." One year later Hoffman (1994, p. 691) depicted two possible scenarios for planning: "a transition similar to what we have seen in Western European countries [or] a transformation that reflects the unique circumstances of the country".

However, in terms of participation the expectations towards a Western-like democratization path were strong. Participation in the CEE countries was perceived to be 
difficult, but the call for increased participation was almost unanimous (Hoffman, 1994; Maier, 1998; Nedovic-Budic, 2001). With regard to the Czech Republic, Hoffman (1994, p. 696) wrote: "after 1989, the intent was to make the planning process participatory; yet it remains difficult to get people civically involved."

This was a turbulent period for planning. The legacy of planning was the strict ideological control, which converted it into a "mere technical discipline" (Maier, 1998). The new circumstances were characterized by the increased role of self-governments, the rise of market forces and civil freedoms. In this context, increased participation was expected to be the "byproduct of the more democratic political environment, with more open communication between the government and the citizens" (Nedovic-Budic, 2001, p. 46). We can identify this expectation in Maier's (2001) hypothesis as well. He reported and also envisioned the widening of participation in planning:

\footnotetext{
"Increasing participation [...] might best be compared to the effect on the surface of a lake after a stone has been thrown in. Larger and wider circles of interest groups or 'stakeholders', each who claim a right to be heard and involved, emerge around the spot where the stone penetrated the water's surface - which symbolizes an initial 'power centre' where decisions are made. [...] The interaction between the power centre and an 'outside' stakeholder would gradually pass through several stages which are similar to the Arnstein's rungs of ladder” (Maier, 2001, p. 716).
}

According to Maier (2001), increasing circles of stakeholders will gradually join the planning process. First by struggling for legitimization, then they becoming visible for the power centre and would be accepted as "regular opponents". In further stages they may develop alternative concepts of planning, which finally may be incorporated into mainstream planning.

Therefore, he put forth a two-dimensional process, where one dimension is about gaining recognition, while the other dimension is about the changing of the power relations. $\mathrm{He}$ suggested that such a process would (should) be a combination of bottom-up and top-down efforts, and that it is a learning process for both the interest groups, citizens and the governments.

The path Maier (2001) hypothesised was characterised by factors that are in line with the Western-like urban planning participation. Later, when he reviewed the change in planning in certain CEE countries, he also highlighted the similarities of the influencing factors in CEE and Western-European countries (Maier, 2012, p. 150):

\footnotetext{
"The factors that frame spatial planning in the East-Central European countries are not essentially different from the factors elsewhere. The differences rest upon different priorities and less balanced
} 
sharing of power: in particular, the position of citizens is weak in the triangle of business, authorities and politicians, and citizens.”

However, at least in Hungary, the 2010s proved to unfold a path, in which the difference may not solely lie in the priorities, but the objectives themselves. In terms of participation in planning, though, we cannot state that the 2010s opened up a genuinely new path. The direction of change seems to follow a longer trend, which began much earlier.

\section{The changing Hungarian context of participation}

In Hungary, similar to other post-socialist countries, the new legal framework for participation in planning was set up in the 1990s. The new legislation ${ }^{1}$ established the legal basis for stakeholder and citizen participation, primarily with regard to regulatory, land-use planning. The importance of strategic orientation at the local level was, in general, weak. Links towards strategic planning at higher territorial levels, or visions to be considered by regulatory plans were largely missing (Suvák, 2010).

It became clear that the existence of regulation is not sufficient in itself. In Hungary, we could not detect a participatory turn (Jávor \& Beke, 2013). The increased role of selfgovernments did not imply that decision makers would have recognized the possibilities or the necessities of citizen involvement (Földi, 2009; Csanádi, Csizmady \& Köszeghy, 2010). This is not unique among CEE countries. According to Maier (2012, p. 149) "although the reforms of planning laws have established legal preconditions for public participation in planning, community-based, people-friendly planning is still rather wishful thinking."

The theoretical foundations of communicative planning and arguments highlighting the normativity of the planning exercise emerged in the Hungarian planning literature (e.g. Faragó, 1997, 2001). However, this did not imply a shift towards participatory planning. As Faragó (2001) noted, the practice of planning devotes disproportionately high attention to the "objective" foundation of plans (e.g. the assessment of the present situation), and neglect the importance and normativity of the mechanisms of setting objectives.

While planners were liberated from the ideological control of the state, they found themselves amidst new constraints. Csanádi, Csizmady and Kőszeghy (2010) argued that

\footnotetext{
${ }^{1}$ The Act No. 21 in 1996 with regard to spatial planning and the Act No. 78 in 1997 with regard to urban (settlement) planning. These acts, after numerous amendments, are still in force.
} 
planners became largely dependent on local political processes, which, in turn, are heavily influenced by market actors (investors) and the rivalry among cities for development funds.

Later on, new factors started to influence participation in planning, either directly or indirectly. The regulatory environment changed in the early 2010s. The new act on local governments (2011), and new regulations regarding the planning process (2012) came to force. The new act on local government signalled the beginning of a strong re-centralisation process, however, institutional guarantees of decentralization had always been fragile (Pálné et al., 2017). Centralisation has largely intensified since. A spectacular manifestation of that is the central government's currently running "Modern Cities Programme". It is a collection of large urban development projects, with a substantial budget (3400 billion HUF), where all the decisions (including local land use) are made at the national level.

The new regulations regarding the process aspect of urban planning also fitted a longer term tendency. Opportunities for formal participation in the urban planning processes (with regard to major planning documents and urban development projects) have continuously decreased since 2006 (Bajmócy, Gébert, Elekes \& Páli-Dombi, 2016). The legislation provided more and more room for dismissing participation and less and less time for the participatory processes.

Since 2012, contrary to the former unified rules, local governments are allowed to define the set of actors whom they consider to be partners, and the ways they intend to cooperate with them ${ }^{2}$ (in the so called Stakeholder Reconciliation Plan). On the one hand, this served as an impetus for local governments to actually think about whom they consider to be their partners, and what their purpose with the partnership process is. On the other hand, this eradicated the remains of the fragile institutional guarantees of stakeholder and citizen participation.

An important additional factor, which has shaped participation in urban planning is the importance of the EU funds in urban development. The scope of planning has been narrowed down in many ways, which obviously affected the meaningfulness of participatory processes. Planning has been totally and constantly funding-oriented, the objectives of the EU funds and the national strategic reference frameworks (New Hungary Development Plan, Széchenyi 2020 Plan) narrowed down the possible scope of bottom-up visioning (Mezei, 2006; Faragó,

\footnotetext{
${ }^{2}$ Apart from a few public bodies, which are compulsory partners.
} 
2012). Furthermore, the uniform EU standards (presumptions about the adequate processes, tools, and meanings attached to concepts such as space, participation, governance or strategic planning) did not necessarily have a good match with the everyday realities of Hungarian actors (Varró \& Faragó, 2016).

As a consequence, participation occurs in a controversial way in the Hungarian urban planning practice. On the one hand, certain formal channels of stakeholder participation (including civil society organizations and citizens) are present; stakeholders do participate to a certain extent. (e.g. Nárai \& Reisinger, 2016). On the other hand, this does not necessarily mean meaningful participation. Bajmócy et al. $(2016,2020)$ argued that participation in urban planning is mainly rhetorical, it does not have any influence on the power relations, largely lacks public deliberation and does not provide real opportunities for agency. The processes do not intend / are unable to empower marginalized groups (Málovics, Juhász, Méreiné \& Tóth, 2017).

\section{METHODOLOGY}

During 2013 and 2014 most of the Hungarian middle-sized cities (namely the 23 cities with the rights of a county) renewed their urban development concepts (UDCs) and integrated urban development strategies (IUDSs). This period was also the debut of a new plan type: the (aforementioned) Stakeholder Reconciliation Plans (SRPs), which served as frameworks for stakeholder and citizen participation.

We started to carry out our analysis right after the passing of the new UDCs and IUDSs.

49 interviews were conducted during 2015 and 2016 with various stakeholders of urban planning in three middle-sized cities: Kecskemét, Pécs and Szeged (Table 1.). Interviewees entered our sample in two ways. On the one hand, we contacted the actors, who formally took part in the planning process; were mentioned by the documents or were active at public discussions in connection with the recent planning process. On the other hand, we also used a "snowball method", and contacted actors who were mentioned during the interviews, or suggested by the interviewees. We did not intend to compare the three cities; neither did we attempt to analyse the opinions of the stakeholder groups distinctly. Our aim was to gain a detailed understanding of the Hungarian practice by bringing on board the diversity of interpretations and contexts. 
Table 1 Distribution of the interviewees among cities and sectors

\begin{tabular}{lccccccc}
\hline City & $\begin{array}{c}\text { Number of } \\
\text { interviewees }\end{array}$ & \multicolumn{6}{c}{ Sector of the interviewee } \\
\cline { 3 - 7 } & & $\begin{array}{c}\text { Civil } \\
\text { society } \\
\text { organization } \\
\text { (CSO) }\end{array}$ & Research Business & Politics & $\begin{array}{c}\text { Mayor's } \\
\text { office and } \\
\text { public sector } \\
\text { enterprises }\end{array}$ & Planning \\
\hline Kecskemét & 15 & 9 & 2 & 4 & 3 & 2 & 1 \\
Pécs & 19 & 2 & 6 & 6 & 3 & 4 & 8 \\
Szeged & 15 & 5 & 1 & 6 & 4 & 1 & 4 \\
Sum & $\mathbf{4 9}$ & $\mathbf{1 6}$ & $\mathbf{9}$ & $\mathbf{1 6}$ & $\mathbf{1 0}$ & $\mathbf{7}$ & $\mathbf{1 3}$ \\
\hline
\end{tabular}

Note: An interviewee may be embedded into more than one sector. Present table considers "multiple identities" of the interviewees.

We conducted semi-structured interviews and we used a "traveller" interviewing method (Brinkmann \& Kvale, 2015). We used very general questions about urban development and planning to initiate the dialogue. We let the interviewees to introduce the exact topics. It was up to the interviewees whether they started to talk about formal or informal planning, strategic or land-use planning, programming or political cycles, etc. The word-by-word transcripts of the interviews served as a basis for the analysis.

We carried out qualitative content analysis (Titscher, Meyer, Wodak \& Vetter, 2000). We attempted to go beyond the surface structure of the texts and deal with the deep structures. We contrasted different parts of the same interviews and also parts of different interviews in order to arrive to coherent "stories" about participation. This allowed us to identify why participation occurs in certain ways; in other words, to identify the underlying factors that shape the framework of participation in urban planning in Hungary.

Since we were interested in the underlying factors of participation we did not use any predefined theoretical categories for the analysis. Instead, we began with an inductive coding approach: we classified the relevant parts of the texts into categories that emerged from the interviews. The categories emerging from the texts were inevitably contrasted with the prior theoretical knowledge of the analysist. This process eventually led us to come up with six main categories of the underlying factors of participation.

\section{RESULTS}

Based on the interviews, we identified six re-occurring themes, which shape the frameworks of participation in urban planning through various channels. These are factors that seem to operate in various contexts (in all the analysed cities) and shape the way participation occurs for and the way it is perceived by different actors. These are: re-centralization, unbalances in 
various power hierarchies, actors' strong alternative towards a negotiated agreement, the unique position of the planners, the experience regarding participation that has accumulated since the regime change and opting out from participation.

\section{Re-centralization}

We found, that re-centralization affects the framework of participation in various ways. Obviously, the more decisions are made at higher levels, the less room there is locally for discussions; and the more importance the hidden and invisible forms of power have. Therefore, participatory processes become superfluous or impossible in many cases.

But centralization has its effects also when participatory processes do take place. According to numerous interviewees (from all examined sectors), the framework conditions of participation (e.g. timeframe, changing and chaotic requirements of planning) are heavily influenced from the higher territorial levels. This easily makes participatory processes illdesigned and the spaces of participation purified.

\footnotetext{
"Everything's told at the central level [...]. Why on earth do we prepare these lots of documents, when the IUDSs look like the same in all cities [...]; they look like Budapest wants them." [28, public sector \& planning]

"Our aim with the strict deadlines was not to narrow down the channels of consultation, we simply had these impossible timeframes." [47, planning]

“As far as I see, [local] politics wouldn’t be happy at all, if citizens had a say.” [10, politics \& CSO]
}

While many actors agree that centralization degrades the possibilities of real participation locally, some (mainly civil society actors and some politicians) also emphasize that local politics and bureaucracy willingly accepts such conditions. Local power holders are not interested in transparent and participatory processes either.

\section{Unbalances in various power hierarchies}

We found that participation cannot be well understood if we characterize actors merely on the basis of their sector, or their distance from the power centre (regarding the visible form of power). Actors usually have "multiple identities" (e.g. politics and civil society; business and planning; research and planning; research and business etc.); while representing organizations they also act and evaluate local processes as citizens; they take part in various power hierarchies and their positions in the different hierarchies may be fairly different. 
The actors' opportunity to participate effectively and to further their own ends in the urban planning process depends on their position in a matrix of various hierarchies (e.g. actors may have different positions regarding visible and hidden power). For example, certain members of the city council actually have very limited possibilities to take part effectively, certain businessmen or organizations may be very influential without any visible power.

\footnotetext{
"We sent a proposal; we knew by chance that we could [...] rumour had it. The planning process was like this. Some knew about it, some didn't." [15, CSO]

"CSOs are dependent on the local government, not to mention the central one. "Cause they halved the money for the civil sector, and what remained is distributed along political considerations." [10, politics $\& \mathrm{CSO}]$

"The [large corporation] is a major player here. [...] It is reasonable to reconcile, in the sense, whether it has any expectations towards the local government." [5, public sector]

"The mayor invited six intellectuals to write down their opinion [...]. I was one of them [...] of course the only woman." [26, public sector \& planning]

"When you have a 2/3 majority at any level, then [reconciliation] becomes a make-believe activity. We could experience both at the national and also the local level, what it means to have a comfortable majority in the city council, in the committees, wherever. You can do anything." [46, politics \&CSO]
}

According to the interviewees' perception, overall power unbalances are striking. Few actors manage to hold strong positions in multiple power-hierarchies, while others may be excluded through various channels. The most important channels of exclusion are: economic interest over social/environmental considerations; delegates over ordinary citizens; experts over laypeople; funders over fund receivers; employers over employees and male over female.

The presence of the variety of power hierarchies can sometimes be effectively utilized by actors to articulate their values and interest. For example, certain civil society organizations managed to influence decision makers by referring to expertise (instead of democratic values). But sometimes it is the other way round: decision makers can effectively de-legitimize claims by simply switching between channels. For example, they turned down professional claims by emphasizing political factors (and the lack of political legitimacy of the claim makers); and they turned down democratic claims by referring to professional factors (and the lack of expertise of the claim makers).

\section{Strong alternative towards a negotiated agreement}

Centralization and the unbalances in different power hierarchies contribute to the fact, that for most of the local stakeholders, participatory processes are not at all attractive. Very often, participation in urban planning is either superfluous or meaningless for actors. According to Innes (2004), participatory processes are more likely to succeed if actors do not have strong 
alternatives towards participation. She suggested to analyse actors' BATNA (best alternative towards a negotiated agreement). Actors with a strong BATNA can find their ways without having to negotiate with others or can easily violate the agreement later.

We found that in Hungary the alternatives towards negotiated agreements are very strong. First, some actors (central and/or local government together with powerful business actors) can easily intervene and alter the results of negotiated agreements. Urban strategies and land use plans are flexible in this sense.

\footnotetext{
"The link between the decisions of the local government and the [...] process was accidental." [15, CSO] "Even if they [the plans] are written by the best experts [...] local politics and business rewrites them to such an extent, that they can't be realized." [21, research]

"When [a multinational corporation] declared they come to Kecskemét, right before that a new IUDS had just been finished [...] it had to be re-written immediately." [9; CSO]
}

Second, many local politicians and enterprises seem to find their ways easily without having to negotiate with further actors. According to several interviewees (including politicians who are members of the local governing parties), large infrastructural projects and pro-growth policies are thought to be more important for re-election than transparency, consultation, or the attempt to take local knowledge or environmental/social concerns on board.

\footnotetext{
"Processes take place on two levels. There's a visible and there's an invisible process. [...] These are not processes that would reinforce each other." [31, research \& planning]

"The local government commissioned this expert team to prepare the IUDS. At the same time [all the relevant] decisions of same local government were kept secret from the expert team.” [22, planning]
}

Third, visible channels of power and formal spaces of participation seem to be less important than hidden, informal channels. This implies that even actors without an ability to influence decision making may have a good reason to skip formal participation and build capacities in order to have access to informal channels and hidden power. Actors from the civil society sometimes argued that instead of drawing attention to their claims in visible ways (e.g. through demonstrations, open letters etc.) it makes more sense to try to lobby or persuade council members directly. Interviewees from the business sector, when talking about participation, unequivocally talked about access to informal channels (e.g. regular consultations with the mayor) and not better access to formal participatory processes. 


\title{
The unique position of the planners
}

The above factors put planners into a unique and often unpleasant position. Many of the planners, bureaucrats and researchers, who coordinate or create the urban development plans (UDCs and IUDSs) are in favour of participatory processes. However, they are also puzzled by the real-life effects of strategic planning. Numerous interviewees (including planners, researchers, politicians and civil society actors) argue that strategic plans hardly guide reality; the most important part of the plans are the project lists ${ }^{3}$; and politicians deliberately intervene so that the strategic plans cannot cover the issue of governance.

\begin{abstract}
"Decision makers sometimes intervene in a particular way [...]. It's hardly about the process itself, just certain elements. They send a message that this is important for us or consider that. But they can't and don't want to understand the process itself; they don't learn from that. As a consequence, the passing of the strategy is also the death of it and the whole planning process. [...] So long planners, what comes is none of your business; no more questions, reconciliations, forums. [...] And from here the game continues, which is not at all transparent. [...] We were not allowed to analyse governance [...]. There was a general attitude that you're the experts this is your playground, you can play here, and leave the politics for the big boys. [22, planning \& business]

"After writing the 78th document for the drawer, you're really fed up." [31, planning \& research]

"After we finished the document, it was over. They have never contacted us since, not even informally." [25, planning \& business]

"I simply didn't have the possibility for involving citizens, though, it would have been very important. This perspective was missing from the mind-set of the development agency, [...] the political decision makers and also the practitioners." [16; planning]
\end{abstract}

These planners are frustrated by the lack of plans' effects and by the inadequate framework conditions. While they are in favour of participatory processes, they also see that such conditions make meaningful participation difficult or even impossible. They claim that they could and would like to implement better participation but they are hindered by the fixed frameworks. Many of them feel powerless and helpless.

\begin{abstract}
"I think one should reconcile with the citizens only to an extent, [... because it's not their competency. They should accept that you need certain knowledge and wisdom for this. They should accept that their leaders work for their benefit, that's why they were elected." [28, planning \& public sector]

"I believe, planning is a task for experts. [...] If by civil actors we mean well-prepared experts, who are civils, because they do not represent the particular interest of certain organizations, then they have a place [in the planning process].” [41, planning \& research]
\end{abstract}

There also exists another group of planners, bureaucrats and researchers (especially with regard to project and land use planning) who do not deem stakeholder and citizen participation to be important (except for the participation of the powerful economic actors).

\footnotetext{
3 According to many interviewees, the project list is basically a wish-list, which can change quickly and radically. Only those projects are listed, which are planned to be implemented by external (mostly EU) development funds.
} 
Their planning style is dominated by the idea of rational planning and programming (see Maier, 2012), which makes the exclusion of the laypeople evident. For them participation is a barrier to efficiency; it is also a threat, which may introduce political claims into the realm of expertise; or may simply be redundant.

\section{Experience regarding participation}

Almost all the actors have unpleasant experience with participatory processes. In this respect one of the examined cities differed a little bit. Here, bottom-up initiatives were clearly present and planners put a lot of effort in experimenting with participatory techniques. However, the majority of interviewees argued that participatory processes eventually became co-opted by the politics and ceased without any significant effect on real-life decisions.

\footnotetext{
"I don't remember being asked about things that actually have significance." [2, CSO]

"You can have a say in minor things, but never with regard to conceptual matters." [39, CSO]

"We gave so much energy to this city, and the city just didn't want it, and deceived the civil sphere." [22, planning]

"We are listed as partners, so we must be asked, but in fact, I didn't realize, they would have asked us." $[34, \mathrm{CSO}]$

"The planner prepared the document $[\ldots]$ and they set up four working groups [...]. But they invited them only to [...] legitimize what they had already done." [49, business]
}

The overwhelming majority of interviewees representing civil society organizations or small enterprises had bad experience with participation in urban planning. With regard to strategic planning, they argued that the effort and time they devoted was totally in vain. With regard to project and land use planning their everyday reality was a continuous conflict situation with the planner side. They often felt that participatory processes were dishonest, manipulative; they even felt exploited. Open public deliberation or joining forces through consensus-oriented participatory techniques were very far from their everyday reality.

\footnotetext{
"In Hungary, participation is not really part of the culture. I feel, we did all we could with personal invitations, we provided opportunity, but we cannot force anyone to take part." [40, planning \& public sector]

"You know how it is usually, only those come to these forums who are discontent. So the outcome [of these forums] is always negative. Those who are satisfied, they stay at home.” [18, planning \& research]
}

Many actors from the planner side had bad experience with participatory processes as well. Apart from a few researchers/planners, they argued that participatory processes are not rewarding. However, they hardly reflected on the fact that the experience they have with 
participation mostly stems from cases with pre-fixed framework conditions and simple (nondeliberative) techniques.

\section{Opting out from participation}

Due to the above-mentioned factors, several actors are deeply sceptic about the meaningfulness of participatory processes around strategic and land use urban planning. Therefore, in many cases they opt out from participation. In the perception of many interviewees, plans will not guide reality, values and interests cannot be effectively articulated through the formal (visible) channels and certain actors could easily misuse the process or violate the agreements.

\footnotetext{
"To put it mildly, the result of the preceding process do not affect the decisions. Either the complete opposite will happen, or focus is shifted to such and extent [...] that you won't devote time, energy and efforts to take part next time." [35, CSO]

"I must admit, I didn't really care about the development processes. [...] I took part [forums] a few times. The mayor talked about the strategic directions [...], but I didn't find the small enterprises or the common people in them. [...] They may not be excluded rhetorically, but in fact they are excluded." [4, CSO]

"Now I think just like the representatives of the business sphere did; that things won't be decided there. Neither the participatory process, nor the planners will affect substantially what will happen in the city." $[17$, planning \& research]

"As I look at it now, I have a dilemma, how much effort these things [being an active citizen] worth. After experiencing that I don't have any chance to change things [...] should I go on and struggle or try to exclude myself from this story?" [36, CSO]
}

On the top of this, interviewees listed additional factors, which make them not to participate even in cases they could. First, some of the actors disagree with the premises on which urban development discussions are based (e.g. growth-oriented thinking, big solutions, competitiveness etc.). They feel that they have nothing to do with the ongoing discourse (and they do not have any power to change that). Second, several interviewees (mainly from the civil sector) argued that the quality of the plans is seriously reduced without the local knowledge. But participatory processes do not intend to take the knowledge of the local actors on board. Third, many of the local actors have long history (of cooperation or conflict) with each other. Therefore, certain stakeholders (including actors from the planner side) may regard each other to be discredited.

\section{DISCUSSION AND CONCLUSIONS}

According to Maier's (2001) hypothesis, the democratization process in the CEE countries would lead to the increased importance of stakeholder and citizen participation in urban 
planning. Increasing circles of stakeholders would be able to join, and become empowered. He envisioned this process as a combination of bottom-up and top-down efforts.

Maier (2012) argued that the differences between Western-Europe and the CEE countries are not fundamental with regard to urban planning. The basic factors that frame planning are the same, but there are differences in the priorities and in the balance of power among actors. He urged CEE countries to move beyond the formal (and rhetoric) alignment of planning to the EU frameworks and principles.

In other words, we can interpret Maier's expectation in the following way: the democratization path as a fundamental underlying process, and the ability of various actors to approximate values and interests (the ability to combine bottom-up and top-down efforts) make urban planning in Western-Europe and in the CEE countries somewhat similar. They can be examined and interpreted within the same conceptual framework ${ }^{4}$. However, our results question the validity of these two very fundamental assumptions (at least in the case of Hungary).

After the regime change, there surely was an experimental period, when different paths were open. But the democratization process with regard to planning took an unfortunate turn. Notwithstanding Maier's hypothesis, participation in urban planning has been mostly emptied out. The strong re-centralization, unbalances in various power hierarchies and partially the role played by the planners ${ }^{5}$ hindered and still hinder the democratization of urban planning. In order to arrive to a more meaningful participation, various power hierarchies should be challenged, e.g. national vs. local; representative vs. citizen; expert vs. lay; visible vs. hidden/invisible power.

Participatory processes in urban planning are generally rooted in the idea of consensus seeking. Based on the abundant empirical evidence present in the planning literature, Innes (2004) argues that the pre-requisite for consensus building is an authentic dialogue. This means that:

- The interest and values of stakeholders differ, which makes consensus seeking necessary.

- None of the major stakeholders are in a position where they can arrive to a satisfactory solution without taking part in the process. So participation has a real

\footnotetext{
${ }^{4}$ This does not imply that urban planning would be uniform either in Western-Europe or in the CEE countries. Of course, there exist different planning styles, various local contexts, etc. The argument solely refers to the existence of certain fundamental similarities with regard to the framework of participation in urban planning.

${ }^{5}$ As mentioned in the results section, the role of planners with respect to participation is manifold. In some cases, the way planning occurs hinders democratization and consensus-seeking. In other cases, their role is exactly the opposite.
} 
stake for the actors. In other words, actors do not have a strong BATNA (a strong alternative towards a negotiated agreement).

The strong power hierarchies, the strong alternative towards negotiated agreements, the experience of actors with former participatory processes, opting out and partially the role played by planners do not help the approximation of values and interests. In other words, we found that the fundamental pre-requisites of an authentic dialogue do not hold true in the case of Hungarian urban planning.

On this basis we can link back to our research questions. The identified underlying factors (and their interaction) fuel processes that diverted Hungary from the path Maier (2001) envisioned in his hypothesis (Figure 1.). The factors that shape the framework conditions of participation in planning add up to a halt in the democratization of planning and the serious limits to consensus building. We believe, democratic standards and consensus building are fundamental characteristics of the Western-European-like planning, to which CEE countries were so eager to approximate to after the regime change. Therefore, in case of Hungary, we cannot reinforce Maier's hypothesis.

Figure 1. Most important influencing factors of participation in urban planning in Hungary

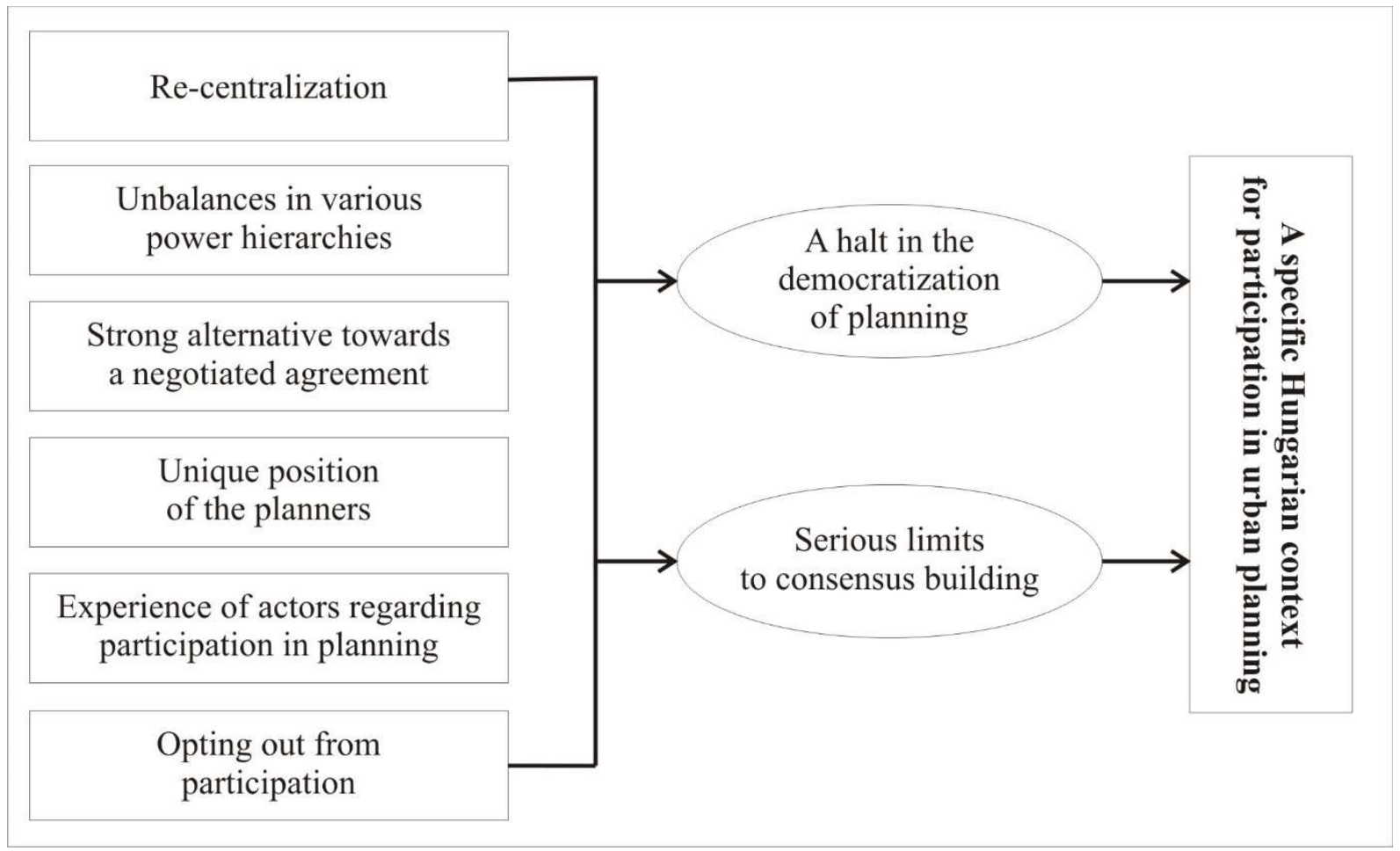

Source: own construction 
The post-socialist legacy may have some indirect influence on the identified factors. But most of them (e.g., centralization, the strong BATNA, the unpleasant experience of actors with participatory processes etc.) have accumulated since the regime change. It suggests that the post-socialist legacy allows for multiple paths (including the good fit of WesternEuropean planning styles and techniques as well as its complete opposite).

Our results have certain theoretical and practical consequences, which may open up new research directions regarding urban planning in post-socialist contexts, or call for changes in the practice of planning. First, both theory and practice should pay more attention to the complexity of actors and their relations. It is very usual to characterize actors on the basis of their sector (i.e., business, government, academy, civil, etc.) (e.g., Swinburn, Goga \& Murphy, 2006; Lengyel, 2010); or on the basis of a single dimension (e.g., their distance from the power centre) (Maier, 2001). If one bases the design of practical participatory processes or their evaluation on such characterizations, that will lead to the oversimplification of reality. In fact, actors are part of various power hierarchies, which should be grasped through more sophisticated categorisations (e.g. Avelino \& Wittmayer, 2016). Their sector or their position alongside a single dimension does not tell much about their motivations, interests, values or opportunities. Accordingly, the mere fact that actors from various sectors were invited to a process does not tell too much about the quality of the participation.

Second, if the fundamental pre-requisites of an authentic dialogue are not present, even very well designed processes, and any efforts of planners who would really like to further participation, may result in un-authentic dialogues. If this remains un-reflected, participatory processes may easily become co-opted, be misused, and reinforce the existing power relations. Of course, the fact that planning processes may reinforce existing power hierarchies are not specific to the CEE context. It is well-known in the planning literature, and serves as a basis for arguments in favour of advocacy in planning (e.g. Davidoff, 1965; Murphy \& FoxRogers, 2014). What seems to be specific to the Hungarian context is that the scope for consensus-seeking techniques is seriously limited. Thus situations, where planners may remain more or less neutral without the risk of strongly reinforcing exiting power hierarchies are extremely rare. This is in strong contradiction to the dominating planning style, which continues to see planning as rational, neutral or objective (Faragó, 2001; Lengyel, 2010; Maier, 2012).

While our results only refer to Hungary, they may have certain implications for other countries as well. The factors that diverted Hungary from the path envisioned by Maier (2001), may have relevance in other contexts as well. It seems to be a very important lesson 
that participation in planning cannot be detached from the general democratization trends. And it also seems to be clear how strong (re)centralisation hinders meaningful participation at the local level. A further implication is that a mere change in the planning style is not enough to bring about meaningful participation. Without the pre-requisites of authentic dialogues planners will be just a further group of actors being discontent with participatory processes.

Finally, more attention should be paid to the presumptions lying behind certain concepts or techniques pressed by the European level in spatial planning. EU level policies had a good reason to stress the importance of principles such as subsidiarity, participation, and inclusion. But they largely failed to realize that without the general democratization of planning and without the existence of the pre-requisites for authentic dialogues, these principles may work out in ways, which are just the opposite of the original intention. Paradoxically, participatory processes in connection with EU-funded urban planning contributed to the accumulation of unpleasant experience and a general scepticism towards participation.

\section{Acknowledgements}

The present paper utilizes the interviews that were conducted as part of the research project OTKA K109425 supported by the Hungarian Scientific Research Fund. I am grateful to the interviewees for sharing their knowledge and experience and to my colleagues who participated in the interviewing process: György Málovics, Judit Gébert, Boglárka Méreiné Berki and Judit Juhász.

\section{REFERENCES}

Avelino, F., \& Wittmayer, J. M. (2016). Shifting power relations in sustainability transitions: a multi-actor perspective. Journal of Environmental Policy \& Planning, 18(5), 628-649.

Bajmócy, Z., \& Gébert, J. (2014). Arguments for deliberative participation in local economic development. Acta Oeconomica, 64(3), 313-334.

Bajmócy, Z., Gébert, J., Elekes, Z., \& Páli-Dombi, J. (2016). Beszélünk a részvételről... Megyei jogú városok fejlesztési dokumentumainak elemzése az érintettek részvételének aspektusából. Tér és Társadalom, 30(2), 45-61.

Bajmócy, Z., Gébert, J., Málovics, G., Méreiné Berki, B., \& Juhász, J. (2020). Urban strategic planning from the perspective of well-being: Evaluation of the Hungarian practice. European Spatial Research and Policy, 27(1), 221-241.

Basta, C. (2016). From justice in planning toward planning for justice: A capability approach. Planning Theory, 15(2), 190-212.

Basta, C. (2017). On Marx's human significance, Harvey's right to the city, and Nussbaum's capability approach. Planning Theory, 16(4), 345-363.

Biggeri, M., \& Ferrannini, A. (2014). Opportunity gap analysis: Procedures and methods for applying the capability approach in development initiatives. Journal of Human Development and Capabilities, 15(1), 60-78.

Bőhm, A. (1987). A helyi hatalom és a lakossági részvétel esélyei. Tér és Társadalom, 1(1), $17-30$. 
Brinkmann, S. \& Kvale, S. (2015). InterViews. Learning the Craft of Qualitative Research Interviewing. Third edition. Los Angeles, London, New Delhi, Singapore, Washington DC: Sage.

Csanádi, G., Csizmady, A., \& Köszeghy, L. (2010). Nyilvánosság és részvétel a településtervezési folyamatban. Tér és Társadalom, 24(1), 15-36.

Czupich, M. (2018). Level of Social Participation in the Creation of Urban Regeneration Programmes. The Case Study of Small Towns in Poland. European Spatial Research and Policy, 25(2), 81-98.

Davidoff, P. (1965). Advocacy and pluralism in planning. Journal of the American Institute of Planners, 31(4), 331-338.

Fainstein, S. S. (2014). The just city. International Journal of Urban Sciences, 18(1), 1-18.

Faragó, L. (1997). Tervezéselméleti alapvetések. Tér és Társadalom, 11(3), 1-15.

Faragó, L. (2001). Szeletek a tervezés mélyrétegeiből. Tér és Társadalom, 15(3-4), 11-24.

Faragó, L. (2012). Urban regeneration on a 'city of culture'. The case of Pécs, Hungary. European Spatial Research and Policy, 19(2), 103-120.

Földi, Z. (2009). A társadalmi részvétel szerepe a városfejlesztés gyakorlatában. Európai és hazai tapasztalatok. Tér és Társadalom, 23(3), 27-43.

Harvey, D. (1973). Social justice and the city. Baltimore, MD: Johns Hopkins University Press.

Harvey, D. (2003). The right to the city. International journal of urban and regional research, 27(4), 939-941.

Healey, P. (1997). Collaborative planning: Shaping places in fragmented societies. Vancouver: Macmillan International Higher Education.

Healey, P. (2010). Making better places: The planning project in the twenty-first century. Basingstoke: Palgrave, Macmillan.

Healey, P., \& Williams, R. (1993). European urban planning systems: diversity and convergence. Urban Studies, 30(4-5), 701-720.

Hoffman, L. M. (1994). After the fall: crisis and renewal of urban planning in the Czeh Republic. International Journal of Urban and Regional Research, 18(4), 691-702.

Innes, J. E. (1995). Planning theory's emerging paradigm: Communicative action and interactive practice. Journal of Planning Education and Research, 14(3), 183-189.

Innes, J. E. (2004). Consensus building: Clarifications for the critics. Planning Theory, 3(1), 5-20.

Innes, J. E. \& Booher, D. E. (2015). A turning point for planning theory? Overcoming dividing discourses. Planning Theory, 14(2), 195-213.

Jávor, B., \& Beke, Z. (2013). Résztvevők és apatikusak. Adalékok a társadalmi részvétel helyzetéhez Magyarországon. Politikatudományi Szemle, 22(4), 59-89.

Lengyel, I. (2010). Regionális gazdaságfejlesztés. Versenyképesség, klaszterek és alulról szervezödö stratégiák. Budapest: Akadémiai Kiadó.

Maier, K. (1998). Czech planning in transition: Assets and deficiencies, International Planning Studies, 3(3), 351-365,

Maier, K. (2001). Citizen participation in planning. Climbing the ladder? European Planning Studies, 9(6), 707-719.

Maier, K. (2012). Europeanization and Changing Planning in East-Central Europe: An Easterner's View. Planning Practice and Research, 27(1), 137-154.

Málovics, G., Juhász, J., Méreiné Berki, B., \& Tóth, J. (2017). Kinek a részvétele? Mélyszegény társadalmi csoportok valós részvételi lehetősége a helyi fejlesztési döntésekben. In. Bajmócy Z., Gébert J., \& Málovics Gy. (eds.), Helyi gazdaságfejlesztés a képességszemlélet alapján. Szeged: JATEPress: 161-188. 
Marcuse, P. (2009). From critical urban theory to the right to the city. City, 13(2-3), $185-197$.

Mezei, C. (2006). Helyi gazdaságfejlesztés Közép-Kelet-Európában (Local economic developent in the Central and Eastern European Countries). Tér és Társadalom, 20(3), 95-108.

Murphy, E. \& Fox-Rogers, L. (2015). Perceptions of the common good in planning. Cities, 42(B), 231-241.

Nárai, M. \& Reisinger, A. (2016). Társadalmi felelösségvállalás és részvétel a lokális és területi közösségi folyamatokban. Budapest-Pécs: Dialóg Campus.

Nedović-Budić, Z. (2001). Adjustment of Planning Practice to the New Eastern and Central European Context, Journal of the American Planning Association, 67(1), 38-52.

Pálné Kovács, I., Bodor, Á., Finta, I., Grünhut, Z., Kacziba, P., \& Zongor, G. (2017). Farewell to decentralisation: The Hungarian story and its general implications. Croatian and Comparative Public Administration, 16(4), 789-816.

Sen, A. K. (1999). Development as Freedom. Oxford, New York: Oxford University Press.

Sen, A. K. (2009). The idea of justice. Cambridge, MA: Harvard University Press.

Suvák, A. (2010). Integrated urban development strategies-comparison of European and Hungarian approaches. Journal of Landscape Studies, 3(3), 139-146.

Swinburn, G., Goga, S., \& Murphy, F. (2006), Local Economic Development: A Primer. Developing and Implementing Local Economic Development Strategies and Action Plans. Washington, DC: The World Bank.

Titscher, S., Meyer, M., Wodak, R. \& Vetter E. (2000). Methods of Text and Discourse Analysis. London, Thousand Oaks, New Delhi: Sage Publications.

Tsenkova, S. (2007). Reinventing Strategic Planning in Postsocialist Cities: Experiences from Sofia, European Planning Studies, 15(3), 295-317.

Varró, K., \& Faragó, L. (2016). The politics of spatial policy and governance in post-1990 Hungary: The interplay between European and national discourses of space. European Planning Studies, 24(1), 39-60. 